\title{
Undifferentiated Carcinoma of the Larynx in a Developing Community
}

\author{
Wilson IB Onuigbo* \\ Department of Pathology, Medical Foundation and Clinic, Nigeria
}

Submission: December 18, 2018; Published: January 17, 2019

*Corresponding author: Wilson IB Onuigbo, Department of Pathology, Medical Foundation and Clinic, 8, Nsukka Lane, Enugu 400001, Nigeria

\author{
Abstract \\ A rare form of laryngeal carcinoma is the undifferentiated form. There are but a few cases in the literature. Therefore, two cases from among \\ the Ibos of South Eastern Nigeria are deemed to be worthy of documentation.
}

Keywords: Larynx; Undifferentiated carcinoma; Ibos; Males; Rarity

\section{Introduction}

A search of the Internet revealed but a few reports on the larynx exhibiting undifferentiated carcinoma. From Turkey [1], a 7-year-old male patient was reported to have "Undifferentiated laryngeal carcinoma with pagetoid spread." From both France [2] and India [3], the authors went as far as to differentiate undifferentiated carcinoma of "nasopharyingeal type." In this context, another differentiation was mooted in USA as the "small cell" type [4]. Therefore, the author presents two cases on the strength of carcinomas which were "undifferentiated," the patients being of the Ibo ethnic group [5].

\section{Case Report}

1. NA, a 78-year-old Ibo man, presented to Dr. Udeh at the University of Nigeria Teaching Hospital, Enugu, with the history of cough, hoarseness and weight loss that had lasted for a year. Tracheostomy tube was inserted. Direct laryngoscopy was used to take a biopsy. Thereafter, the author received pale and dark fragments. On microscopy, much cartilage was seen with malignant epithelial cells whose differentiation was not discerned. Accordingly, it was diagnosed as undifferentiated carcinoma.

2. NF, an 82-year-old Ibo man, attended the Balsam Clinic at Enugu under Dr. Ezeanolue. Hoarseness was of a year's duration. Difficulty in swallowing and stridor were lasting for 3 months. A few small, pale fragments were biopsied. The corresponding author received them. On processing, malignant epithelial cells were seen, no differentiation being apparent. Accordingly, undifferentiated carcinoma was diagnosed.

\section{Discussion}

In pursuit of these researches, the useful pool had come from Birmingham (UK). The group there had hypothesized that the fruit is "epidemiological analysis" whereas planting the tree constituted "the histopathology data pool" [6]. So far, apart from another "undifferentiated" carcinoma [7], the past examples in my collection are the following: clear cell [8], papillary [9], adenoid cystic [10], inflammatory [11], and mucoepidermoid [12]. Curiously, the connection between the "undifferentiated" carcinoma and the "differentiated" type emerged in Japan [13]. There, a 78-year-old man presented with undifferentiated carcinoma of the anal canal. However, at necropsy, it was found that he had "metastatic squamous cell carcinoma to inguinal nodes."

\section{References}

1. Sarioglu S, Dogan E, Sahin Y, Uzun E, Bekis R, et al. (2016) Undifferentiated laryngeal carcinoma with pagetoid spread. Head Neck Pathol 10(2): 252-255.

2. Micheau C, Luboinski B, Schwaab G, Richard J, Cachin Y (1979) Lymphoepitheliomas of the larynx (undifferentiated carcinomas of nasopharyngeal type). Clin Otolaryngol 4(1): 43-48.

3. Bansal S, Shankar A, Gupta AK (2011) Undifferentiated carcinoma of larynx of nasopharyngeal type. Online J Hlth Allied Sci 10(1): 24.

4. Mills SE, Cooper PH, Garland TA, Johns ME (1983) Small cell undifferentiated carcinoma of the larynx: Report of two patients and review of 13 additional cases. Cancer 51(1): 116-120.

5. Basden GT (1966) Among the Ibos of Nigeria. London: Frank Cass.

6. Basden GT, Macartney JC, Rollaston TP, Codling BW (1980) Use of a histopathology data pool for epidemiological analysis. J Clin Pathol 33(4): 351-353.

7. Onuigbo WIB (2018) The palate: Undifferentiated carcinoma. Glob J Otolaryngol 15(2): 1-2.

8. Onuigbo WIB (2017) Clear cell carcinoma of the breast in a developing community: What of the kidney? MOJ Proteo Bio inform 5(6): 00178.

9. Onuigbo WIB (2017) Forensic identification of papillary adenocarcinoma of the lung in a developing community. J Forensic Sci Crim Invest 3(4): 1-2. 
10. Onuigbo WIB (2017) Early case of mammary adenoid cystic carcinoma described in 1881. J Gynecol Women's Hlth 6(3): 1-2.

11. Onuigbo WIB (2017) Inflammatory breast carcinoma in a developing community. Intl J Cell Sci Mol Biol 2(5): 1-3.

This work is licensed under Creative Commons Attribution 4.0 License

DOI: 10.19080/IJCSMB.2019.05.555668
12. Onuigbo WIB (2018) The palate: Mucoepidermoid carcinoma. Glob J Otolaryngol 15(2): 1-2.

13. Inagaki M, Yamazaki H, Saito T (2006) Undifferentiated carcinoma of the anal canal with metastatic squamous cell carcinoma of the inguinal lymph node. Jap J Gastroenterol Surg 39(1): 126-131.

\section{Your next submission with Juniper Publishers will reach you the below assets}

- Quality Editorial service

- Swift Peer Review

- Reprints availability

- E-prints Service

- Manuscript Podcast for convenient understanding

- Global attainment for your research

- Manuscript accessibility in different formats

( Pdf, E-pub, Full Text, Audio)

- Unceasing customer service

Track the below URL for one-step submission https://juniperpublishers.com/online-submission.php 